\title{
Kajian Faktor Pendukung Penumbuhan Mina Eduwisata (Studi Kasus di Kelurahan Tanjung Pauh Kecamatan Payakumbuh Barat Kota Payakumbuh Provinsi Sumatera Barat)
}

\author{
[Study of Supporting Factors for The Growth of Mina Eduwisata (Case Study in \\ Tanjung Pauh Sub-District, West Payakumbuh District, Payakumbuh City, \\ West Sumatra Province)]
}

\author{
M. Syaiful Yutra ${ }^{1}$, Ade Sunaryo ${ }^{1}$, Abdul Hanan ${ }^{1}$, Revelly Junan ${ }^{2}$ \\ ${ }^{1}$ Program Studi Penyuluhan Perikanan, Politeknik Ahli Usaha Perikanan \\ Jl. Cikaret No. 2, Bogor Selatan, Kota Bogor \\ ${ }^{2}$ Balai Pelatihan dan Penyuluhan Perikanan Medan \\ Jl. Chaidir, Nelayan Indah, Kec. Medan Labuhan, Kota Medan
}

Diterima: 7 Agustus 2021; Disetujui 31 Desember 2021

\begin{abstract}
Abstrak
Mina Eduwisata adalah suatu konsep edukasi perikanan yang dipadukan dengan pariwisata dan berbasis pada suatu wilayah yang potensial. Upaya yang dilakukan dalam penumbuhan suatu wilayah menjadi kampung mina eduwisata adalah mulai dari perbaikan teknologi budidayanya. Salah satunya dengan inovasi penggunaan probiotik dari toga dan pemanfaatan pakan alami azolla microphylla. Penyuluhan merupakan langkah untuk menyampaikan informasi tentang teknologi sehingga sasaran atau pelaku utama bisa mengadopsi inovasi tersebut. Tujuan penelitian ini adalah membentuk kelurahan Tanjung Pauh sebagai Kampung Mina Eduwisata dengan penguatan dan pengembangan kegiatan budidaya lele melalui penggunaan teknologi probiotik, pemanfaatan pakan alami Azolla microphylla pada pembudidaya ikan nila, programprogram ini dilakukan untuk dapat meningkatkan ekonomi dan meningkatkan pengetahuan, sikap serta memberdayakan masyarakat sekitar. Penelitian ini berlokasi di Kecamatan Payakumbuh Barat, Kota Payakumbuh, Sumatera Barat. Hasil penelitian menujukan bahwa Kelurahan Tanjung Pauh dikukuhkan menjadi Kampung Mina Eduwisata pada tanggal 14 Juni 2021.
\end{abstract}

Kata kunci: mina eduwisata; penyuluhan perikanan; inovasi budidaya

\section{Abstract}

Mina Eduwisata is a fishery education concept combined with tourism and based on a potential area. Efforts made in growing an area into a mina eduwisata village are starting from improving its cultivation technology. One of them is the innovative use of probiotics from Toga and the use of natural feed, Azolla microphylla. Extension is a step to convey information about technology so that the main target or actor can adopt the innovation. The purpose of this study was to establish the Tanjung Pauh village as a Mina Eduwisata Village by strengthening and developing catfish cultivation activities through the use of probiotic technology, the use of natural feed Azolla microphylla inTilapia cultivators, these programs are carried out to improve the economy and increase knowledge, attitudes and empower the surrounding community. This research is located in West Payakumbuh District, Payakumbuh City, West Sumatra. The results showed that Tanjung Pauh Village was confirmed as Mina Eduwisata's village on June 15, 2021.

Keywords: mina eduwisata; fisheries extension; cultivation innovation

Penulis Korepondensi

M. Syaiful Yutra | mhdsyaifulyutra@gmail.com 


\section{PENDAHULUAN}

Kota Payakumbuh memiliki potensi perikanan yang mumpuni dalam bidang budidaya dan pengolahan. Memanfaatkan potensi perikanan tersebut diperlukan pengembangan potensi Sumber Daya Manusia yang menjadi motor penggerak bagi aspek perikanan. SDM yang kuat dan berkualitas juga akan memberikan peran utama dalam melakukan usaha perikanan agar mampu berorientasi pada kesejahteraan, pembangunan nasional dan bersaing dalam peningkatan produksi. Salah satu kecamatan paling berpotensi di Kota Payakumbuh adalah Payakumbuh Barat.

Kecamatan Payakumbuh Barat terdiri dari 17 Kelurahan. Kelurahan Tanjung Pauh merupakan kelurahan di Kecamatan Payakumbuh Barat yang produksi ikan lelenya terbesar di Kota Payakumbuh. Perikanan budidaya ini menyumbang produksi ikan lele sebesar $30 \%$ untuk Kota Payakumbuh, hal ini berdasarkan perhitungan kami bersama penyuluh perikanan yang membina wilayah Kecamatan Payakumbuh Barat. Terdapat 3 kelompok pembudidaya ikan (Pokdakan) di Kelurahan Tanjung Pauh yang seluruh anggotanya adalah melakukan budidaya ikan lele. Permasalahan yang telah diidentifikasi pada saat penelitian sebelumnya (21 November 202020 Januari 2021), adalah semakin kurangnya perlakukan terhadap pengelo- laan kolam sebelum budidaya oleh pelaku utama. Perlakuan tersebut antara lain penggemburan dasar kolam, pengeringan, pengapuran, dan pemupukan. Tidak adanya perlakuan tersebut mengakibatkan tumbuhnya hama dan penyakit. Hama dan penyakit yang tidak ditangani dengan baik dan benar yang mengakibatkan tingkat produksi ikan lele rendah. Sementara itu harga pakan yang digunakan relatif mahal untuk pelaku utama budidaya Nila di Pokdakan Tobek Ngoji Jaya Kelurahan Tanjuanggodang Sungaipinago. Hal tersebut ditambah kurangnya pengetahuan pelaku utama terhadap pakan alami Azolla microphylla.

Mina Eduwisata adalah kampung perikanan berbasis pendidikan. Penetapan suatu daerah menjadi Kampung Mina Eduwisata apabila memiliki keunggulan pada 3 aspek. Diantaranya aspek Mina (perikanan), aspek Edukasi (Pendidikan), dan Aspek Wisatanya. Pemilihan Kelurahan Tanjung Pauh yang akan menjadi kampung mina eduwisata ini karena memiliki potensi perikanan yang unggul, terutama dari segi pakan alternatif kulit ayam dan dari segi penyumbang produksi budidaya ikan lele terbesar di Kota Payakumbuh. Selain itu dari aspek wisata, Kelurahan Tanjung Pauh juga memiliki wisata yang barubaru ini nyentrik di kalangan masyarakat Kota Payakumbuh. Wisata ini terletak di pinggiran sungai Batang Agam yang 
melintasi Kelurahan tersebut yaitu Kawasan BWS Batang Agam. Kemudian dari aspek pendidikan, para pelaku utama di Kelurahan Tanjung Pauh sudah sering menjadi pemateri dalam rangka kegiatan Sekolah Lapang yang diadakan oleh Dinas Pertanian Kota Payakumbuh.

Kekuatan di 3 aspek inilah yang menjadi standar dalam penetapan Kelurahan Tanjung Pauh menjadi Kampung Mina Eduwisata.

Selain itu, budidaya ikan lele di Kelurahan Tanjung Pauh yang sangat unggul akan produksinya, ternyata masih terdapat permasalahan pada kegiatan pra produksinya. Selain itu, penggunaan pakan alternatif kulit ayam membuat kondisi amoniak kolam meningkat. Apabila permasalahan ini dibiarkan atau tidak ada penanganan lebih lanjut, maka produksi ikan lele di Kelurahan Tanjung Pauh akan menurun. Atas dasar inilah, penggunaan probiotik di terapkan pada budidaya ikan lele.

Lain halnya pembudidaya ikan Nila yang berada pada Kelurahan Tanjuanggodang Sungaipinago yang memiliki permasalahan dari segi biaya produksi. Saat ini, pembudidaya ikan nila masih menggunakan pelet komersial dalam kegiatan produksinya. Tentu hal ini akan mengurangi keuntungan karena besarnya biaya pakan. Atas dasar inilah, pemanfaatan pakan alami Azolla microphylla di terapkan pada pembudidaya ikan nila di Kelurahan Tanjuanggodang Sungaipinago dalam bentuk pengurangan biaya produksi. Tujuan dari programprogram ini dilakukan untuk dapat meningkatkan ekonomi dan meningkatkan pengetahuan, sikap serta memberdayakan masyarakat sekitar.

\section{BAHAN DAN METODE}

Penelitian adopsi inovasi inisiasi kampung mina eduwisata dilakukan di kelurahan Tanjung Pauh Kecamatan Payakumbuh Barat, Kota Payakumbuh, Sumatera Barat. Kemudian adopsi inovasi pada kolam dempond ikan lele dengan penerapan probiotik ini dilakukan pada Kelompok Kincia Solok Mato Aia di kelurahan Tanjung Pauh. Sedangkan adopsi inovasi sosialisasi Azolla microphylla dilakukan pada kelompok Tobek Ngoji Jaya di Kelurahan Tanjuanggodang Sungaipinago. Penelitian dilakukan selama kurang lebih tiga bulan yaitu pada tanggal 8 Maret 2021 sampai dengan 4 Juni 2021. Sasaran penyuluhan dalam penelitian ini adalah 14 orang anggota Pokdakan Kincia Solok Mato Aia untuk kegiatan dempond probiotik dan inisiasi kampung mina eduwisata, dan 12 orang anggota Pokdakan Tobek Ngoji Jaya untuk kegiatan sosialisasi Azolla microphylla, Pemilihan sasaran responden berdasarkan metode purposive sampling. 
Tabel 1. Program penyuluhan

\begin{tabular}{|c|c|c|c|c|}
\hline No & Program Penyuluhan & Responden & $\begin{array}{c}\text { Jumlah } \\
\text { Responden }\end{array}$ & $\begin{array}{c}\text { Lokasi } \\
\text { (Kelurahan) }\end{array}$ \\
\hline 1 & $\begin{array}{l}\text { Pembentukan Kampung Mina } \\
\text { Eduwisata }\end{array}$ & $\begin{array}{l}\text { Kelompok Perikanan } \\
\text { dan Masyarakat }\end{array}$ & 14 & Tanjuang Pauah \\
\hline 2 & $\begin{array}{l}\text { Dempond Probiotik pada } \\
\text { Budidaya Ikan Lele Mutiara }\end{array}$ & $\begin{array}{l}\text { Pokdakan Kincia } \\
\text { Solok Mato Aia }\end{array}$ & 14 & Tanjuang Pauah \\
\hline 3 & $\begin{array}{l}\text { Pemanfaatan Pakan Alami } \\
\text { Azolla microphylla }\end{array}$ & $\begin{array}{c}\text { Pokdakan Tobek } \\
\text { Ngoji Jaya }\end{array}$ & 12 & $\begin{array}{l}\text { Tanjuanggodang } \\
\text { Sungaipinago }\end{array}$ \\
\hline
\end{tabular}

Tabel 2. Responden Dempond Probiotik

\begin{tabular}{llccccc}
\hline No & $\begin{array}{c}\text { Nama } \\
\text { Pembudidaya }\end{array}$ & $\begin{array}{c}\text { Kode } \\
\text { Kolam }\end{array}$ & $\begin{array}{c}\text { Ukuran } \\
\text { Kolam }\end{array}$ & $\begin{array}{c}\text { Tebar } \\
\text { benih } \\
\mathbf{( k g )}\end{array}$ & $\begin{array}{c}\text { Ukuran } \\
\text { benih } \\
\text { (ekor/ kg) }\end{array}$ & $\begin{array}{c}\text { Perlakuan } \\
\text { Probiotik }\end{array}$ \\
\hline 1 & Nanda & 1 & $9 \times 13$ & 300 & 20 & Pakan \\
2 & Ahmad Fauzan & 2 & $9 \times 13$ & 300 & 20 & Air \\
3 & Gusmardi & 3 & $9 \times 13$ & 300 & 20 & Pakan \& Air \\
\hline
\end{tabular}

Adapun Program penyuluhan yang akan dilakukan dapat dilihat di Tabel 1.

Tabel 1 menjelaskan tentang program-program yang akan diterapkan pada saat Praktik Akhir. Penelitian pada kegiatan dempond akan menerapkan 3 perlakuan yang berbeda pada tiap tiap kolam dengan responden yang berbeda dari Pokdakan Kincia Solok Mato Aia. Wadah budidaya yang digunakan untuk penelitian penggunaan probiotik adalah kolam semi permanen yang dasarnya tanah dengan ukuran kolam dan jumlah tebar yang sama.

Berdasarkan tabel 2, bisa dilihat bahwa untuk 3 responden menerapkan dempond dengan berbeda media pemberian probiotik kepada ikan. Ukuran benih yang dipakai adalah ukuran sortiran yaitu ukuran 50gr/ekor atau setara 20 ekor/kg. ukuran benih yang besar disesuaikan dengan pakan yang diberikan yaitu kulit dan usus ayam. Pedagang ayam potong di Payakumbuh membersihkan ayam langsung dengan menguliti bagian luarnya, berbeda dengan daerah lain di luar Sumatera Barat. Hal inilah yang menjadikan pembudidaya ikan lele di Kota Payakumbuh khususnya Kelurahan Tanjung Pauh memanfaatkan limbah kulit dan usus ayam tersebut untuk dijadikan pakan utama dalam proses produksi budidaya ikan lele.

Kulit dan usus ayam tersebut direbus terlebih dahulu sebelum diberikan kepada ikan. Proses perebusan ini sekitar \pm 15 menit sampai tekstur dari kulit dan usus jadi mudah putus. Selain merebus kulit dan usus ayam, pembudidaya juga mencampurnya dengan limbah sayuran. Sayuran yang menjadi 
limbah juga dimanfaatkan oleh pembudidaya sebagai pakan ikan lele. Perebusan kulit dan usus ayam serta sayuran yang bersamaan dengan darahdarahnya menjadikan sayuran tersebut ikut beraroma daging dan tentu meningkatkan nafsu makan ikan lele. Kekurangan dari pakan kulit dan usus ayam ini adalah pada kandungan amoniak pada dasar kolam yang cukup parah. Hal ini disebabkan juga oleh pengelolaan dasar kolam sebelum produksi yang masih jarang dilakukan oleh pembudidaya. Selain melakukan penyuluhan, penulis juga menerapkan dempond probiotik. Probiotik yang digunakan adalah probiotik yang terbuat dari bahan toga (tanaman obat rumah tangga) seperti temulawak, jahe, bawang putih, kencur, dan di tambah dengan bahan pendukung yaitu Yakult, air cucian beras, dan air bersih. Untuk pembuatan fermentasi probiotik sebanyak 2 jeriken $20 \mathrm{~L}$ dibutuhkan dosis bahan sebagai berikut:

$\begin{array}{ll}\text { Temulawak } & : 1 \mathrm{~kg} \\ \text { Jahe } & : 1 / 4 \mathrm{~kg} \\ \text { Bawang Putih } & : 1 / 4 \mathrm{~kg} \\ \text { Kencur } & : 1 / 4 \mathrm{~kg} \\ \text { Yaqult } & : 4 \mathrm{Buah} \\ \text { Gula Aren } & : 1 / 2 \mathrm{~kg} \\ \text { Air cucian beras } & : \text { Secukupnya } \\ \text { Air Bersih } & : 2 \text { Jerigen } 20 \mathrm{~L}\end{array}$

Bahan-bahan ini kemudian dihaluskan semuanya dan baru dimasukkan ke dalam jeriken. Kemudian didiamkan selama 5 hari di dalam jeriken yang dibuka tutupnya 30 detik per hari. Pengamatan dan pengecekan kualitas air dilakukan tiap 2 minggu sekali. Begitu pun juga untuk pengamatan pertumbuhan berat dan panjang ikan lele dilakukan tiap 2 minggu sekali. Parameter fisik yang diamati adalah temperatur air yang cek menggunakan termometer. Parameter kimia yang amati adalah amoniak dan $\mathrm{pH}$. Amoniak diukur menggunakan water test $\mathrm{NH}^{3} / \mathrm{NH}^{4}+$. Sedangkan untuk $\mathrm{pH}$ di cek menggunakan kertas $\mathrm{pH}$ universal.

Sosialisasi tentang pemanfaatan pakan alami Azolla microphylla pada usaha pembesaran ikan nila dengan metode ceramah dan diskusi. Sasaran dari kegiatan penyuluhan ini adalah kelompok pembudidaya ikan di Kecamatan Payakumbuh Barat, Kelurahan Tanjuanggodang Sungaipinago khususnya Pokdakan Tobek Ngoji Jaya. Media yang digunakan dalam kegiatan sosialisasi tersebut adalah tayangan, folder, dan sebagainya. Penulis dalam hal ini juga membawa langsung Azolla microphylla saat diadakannya kegiatan penyuluhan. Sedangkan untuk inisiasi pembentukan kampung Mina Eduwisata dilakukan di Kelurahan Tanjung Pauh dengan metode Ceramah dan Diskusi. Media yang digunakan adalah folder dan brosur, dengan materi tentang manfaat Kampung Mina Eduwisata bagi setiap unsur yang berada pada Kelurahan Tanjung Pauh. 
Evaluasi hasil penyuluhan penggunaan probiotik, dilakukan menggunakan metode demonstrasi percontohan ikan lele mutiara yang terdiri dari aspek pengetahuan, aspek sikap, maupun aspek keterampilan. Sedangkan evaluasi kegiatan sosialisasi pakan alami Azolla microphylla meliputi aspek pengetahuan dan sikap. Kemudian untuk evaluasi kegiatan inisiasi pembentukan kampung mina eduwisata meliputi aspek pengetahuan dan sikap. Instrumen yang digunakan dalam 3 kegiatan ini adalah berupa kuesioner pada awal (pre-test) dan akhir (post-test) yang telah divalidasi. Data yang diolah menggunakan tabel dan grafik. Data yang diperoleh bersumber dari data primer maupun data sekunder. Data primer dikumpulkan dari hasil penelitian yang dilakukan. Data sekunder diperoleh dari wawancara bersama penyuluh perikanan, pembudidaya, lurah dan LPM, serta pemangku kepentingan.

\section{HASIL DAN PEMBAHASAN}

Kecamatan Payakumbuh Barat merupakan salah satu kecamatan yang ada di Kota Payakumbuh Provinsi Sumatera Barat dengan luas wilayahnya lebih kurang 19,06 km² yang memiliki 17 kelurahan. Jumlah penduduk Kecamatan Payakumbuh Barat berjumlah 53.266 jiwa yang terdiri dari penduduk laki-laki 26.515 jiwa dan perempuan 26.751 jiwa dengan sex ratio 99 yang memiliki 577 Rumah Tangga Perikanan, rata-rata bergerak dibidang budidaya pembesaran ikan dan terdapat 1 usaha pengolahan hasil perikanan. Keadaan topografi Payakumbuh Barat bentuknya beragam antara dataran dan berbukit-bukit yang

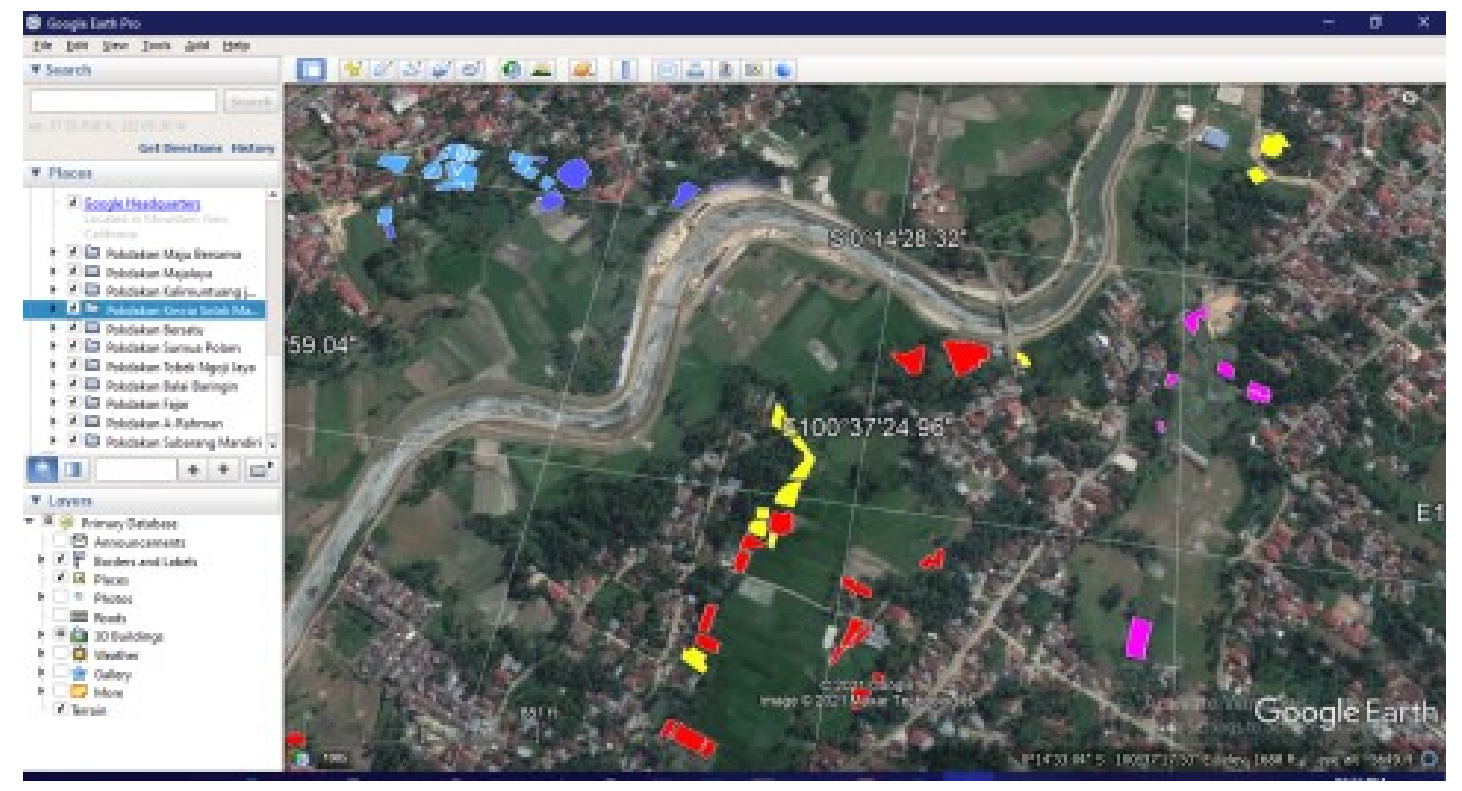

Gambar 1. Peta Poligon Kawasan Kolam Pembudidaya 
Tabel 3. Karakteristik Sasaran Penyuluhan Mina Eduwisata dan Dempond Probiotik

\begin{tabular}{clcccc}
\hline No & \multicolumn{1}{c}{ Nama } & $\begin{array}{c}\text { Usia } \\
\text { (Tahun) }\end{array}$ & $\begin{array}{c}\text { Tingkat } \\
\text { Pendidikan }\end{array}$ & $\begin{array}{c}\text { Lama } \\
\text { Usaha } \\
\text { (Tahun) }\end{array}$ & Segmen \\
\hline 1 & Muhammad Abrar & 54 & SLTA & 10 & Pembesaran \\
2 & Uci Junaedi & 33 & SLTA & 7 & Pembesaran \\
3 & Syafyatul Ziat & 53 & SLTA & 8 & Pembesaran \\
4 & Rohmat & 60 & SLTA & 8 & Pembesaran \\
5 & Zulfikar & 42 & S1 & 8 & Pembesaran \\
6 & Afrinaldi & 42 & S1 & 7 & Pembesaran \\
7 & Ahmad Fauzan & 33 & SLTA & 8 & Pembesaran \\
8 & Agusmardi & 49 & SLTA & 9 & Pembesaran \\
9 & Jeki Sinabuan & 42 & SLTA & 8 & Pembesaran \\
10 & Nanda & 33 & S1 & 7 & Pembesaran \\
11 & Joni Parlin & 42 & S1 & 7 & Pembesaran \\
12 & Zulkifli & 46 & SLTA & 8 & Pembesaran \\
13 & Adus & 46 & SLTA & 8 & Pembesaran \\
14 & Yudi & 27 & SLTA & 4 & Pembesaran \\
& Rata-rata & 43 & & 7,6 & \\
\hline
\end{tabular}

memiliki ketinggian \pm 514 meter di atas permukaan laut. Suhu udara rata-rata $26,50 \mathrm{C}$ dengan kelembaban udara $45 \%$ sampai dengan $50 \%$. Iklim : 260 C-270 C. Kelembaban : $45 \%-50 \%$. kegiatan sektor usaha budidaya perikanan yang dilakukan para pembudidaya yaitu di lahan-lahan sawah yang dialih fungsikan menjadi kolam budidaya (BPS 2020). Peta poligon kawasan kolam-kolam pembudidaya di lokasi penelitian dapat dilihat pada Gambar 1

Pada Gambar 1, kotak-kotak berwarna merah menandakan Pokdakan Kincia Solok Mato Aia, warna kuning untuk Pokdakan Bersatu, warna ungu untuk Pokdakan Sumua Polam dan warna toska untuk Pokdakan Tobek Ngoji Jaya, dan warna lain untuk Pokdakan lainnya. Adapun karakteristik sasaran dari penyuluhan kegiatan dempond probiotik dan inisiasi mina eduwisata bisa dilihat pada Tabel 3 .

Karakteristik pelaku usaha pembesaran ikan nila dapat dilihat pada Tabel 4. Menurut Tanto, Dewi, dan Budio (2012), umur akan mempengaruhi kemampuan fisik dan merespons terhadap hal-hal baru dalam menjalankan usahanya pada usia produktif berkisar antara usia 15-54 tahun. Sasaran kegiatan penyuluhan terhadap 2 kelompok dengan rata-rata usianya 44,5 tahun dikatakan masih sangat produktif, hal ini 
Tabel 4. Karakteristik Sasaran Penyuluhan Sosialisasi Azolla microphylla

\begin{tabular}{clcccc}
\hline No & Nama & Usia (Tahun) & $\begin{array}{c}\text { Tingkat } \\
\text { Pendidikan }\end{array}$ & $\begin{array}{c}\text { Lama Usaha } \\
\text { (Tahun) }\end{array}$ & Segmen \\
\hline 1 & Gusrizal & 55 & SLTA & 7 & Pembesaran \\
2 & Najmul fuadi & 45 & SLTA & 7 & Pembesaran \\
3 & Indrawati & 40 & S1 & 7 & Pembesaran \\
4 & Momon putra & 40 & SLTA & 3 & Pembesaran \\
5 & Zulfaizal & 55 & SLTA & 8 & Pembesaran \\
6 & Sawardi & 44 & SLTA & 7 & Pembesaran \\
7 & Syaflidon A. & 51 & SLTA & 7 & Pembesaran \\
8 & Yandri Naldi & 45 & SLTA & 7 & Pembesaran \\
9 & Dedi Supari & 42 & SLTA & 8 & Pembesaran \\
10 & Deswandi & 49 & SLTA & 6 & Pembesaran \\
11 & Aldi Wiranata & 34 & SLTA & 5 & Pembesaran \\
12 & Farizal M & 52 & SLTA & 8 & Pembesaran \\
& Rata-rata & 46 & & 6,66 & \\
\hline
\end{tabular}

terlihat dari adanya respons terhadap penyuluhan yang dilakukan, cenderung lebih mendengarkan dan mau menerima atau tidak menolak mentah-mentah. Pelaku usaha yang relatif lebih muda umurnya dari umur rata-rata cenderung tidak menerima materi secara langsung melainkan akan mencari terlebih dulu materi yang diberikan kemudian membandingkan materi tersebut. Hal ini menandakan bahwa perkembangan zaman mempengaruhi pola berpikir. Umur pembudidaya berkorelasi erat dengan tingkat keinovatifan dalam berusaha, sedangkan pengalaman usaha yang lama berkorelasi erat dengan keaktifan berkelompok (Hanan, Sinaga, dan Nurmalia 2012).

\section{Mina Eduwisata}

Mina Eduwisata ini adalah sebuah kampung pelatihan tentang edukasi perikanan dipadukan dengan wisata yang ada didaerah tersebut. Alasan inisiasi kelurahan tanjung pauh sebagai kampung mina eduwisata adalah karna kelurahan tanjung pauh memiliki 3 aspek unggulan di Mina Eduwisata ini. Pertama, Mina yang berarti perikanan, pada aspek ini dibuktikan bahwa produksi ikan terkhususnya ikan lele di kelurahan tanjung pauh adalah sebanyak 14 ton per bulannya, atau menyumbang $30 \%$ untuk produksi ikan lele di Kota Payakumbuh. Kedua, Edu yang berarti Edukasi. Dengan memanfaatkan inovasi pakan alternatif dari kulit dan usus ayam dari Pasar Ibuh Payakumbuh, sudah 
menjadikan kelurahan Tanjung Pauh sebagai tempat kunjungan sedari dulu untuk belajar budidaya ikan lele dari masyarakat Payakumbuh maupun dari luar provinsi Sumatera Barat. Artinya pembudidaya di kelurahan Tanjung Pauh sudah bisa membagikan dan menjadi pemateri bagi pengunjung yang datang.

Ketiga, Wisata, menurut Spillane (2002) dalam Diniyah (2018), bahwa suatu daerah yang menjadi tujuan wisata menjadi menarik perhatian apabila memiliki daya tarik wisatanya. Program ini dilakukan untuk menciptakan masyarakat yang sejahtera, maju, dan mandiri. Upaya dalam memberdayakan masyarakat dapat dilakukan lewat beberapa sektor, diantaranya adalah sektor pariwisata. Apabila dikembangkan secara terpadu, sektor pariwisata dapat mendorong sektor-sektor ekonomi lainnya. Pertumbuhan pariwisata yang berbasis pada keahlian masyarakat setempat ialah wujud pemberdayaan masyarakat. Pemberdayaan masyarakat pada bidang ekonomi di dalam sektor pariwisata ialah ekspansi desa wisata bermotif perikanan (Lestari 2010). Dalam menginisiasi pentingnya melakukan pemberdayaan masyarakat di daerah tersebut. Sependapat dengan (Sudarmadji, Hadi, dan Widyastuti 2014), bahwa pemberdayaan masyarakat bertujuan untuk meningkatkan partisipasi dan pemahaman akan pentingnya pengelolaan lingkungan dan potensi sumber daya yang ada.

Spot photobooth merupakan bentuk wujud dari program pendukung dari elemen wisata dalam mendukung penumbuhan konsep mina eduwisata ini. Spot photobooth bertujuan untuk menarik daya tarik saat wisatawan berkunjung yang nantinya secara tidak langsung mereka mempromosikan di akun media saat memposting gambar tersebut. Kelurahan Tanjung Pauh masih memiliki kawasan indah nan elok dan sejuk di sekitar kolam pembudidaya. Selain itu, kelurahan tanjung pauh dilewati oleh aliran sungai Batang Agam yang sekarang sudah menjadi kawasan BWS taman normalisasi Batang Agam.

Mina eduwisata memiliki beberapa kegiatan pelatihan edukasi perikanan sembari berwisata yang nanti akan mengangkat program unggulan dari daerah tersebut. Program ini nantinya menjadi kegiatan yang akan dijalani selama kunjungan dari wisatawan yang ingin mengikuti program tersebut.

Program pelatihan dari kampung Mina Eduwisata ini adalah :

1. Pelatihan budidaya ikan lele sesuai CBIB dengan pakan alternatif kulit dan usus ayam dan juga penggunaan probiotik unggul.

2. Cooking class olahan dari ikan lele seperti rendang dan martabak dari ikan lele. 
3. Wisata perikanan dengan rute menuju kawasan BWS Taman Normalisasi Batang Agam.

Leaflet yang disebarkan untuk menunjang promosi seperti pada gambar 2. Program Mina Eduwisata ini akan membawa dampak positif bagi masyarakat perikanan maupun non perikanan yang ada pada daerah tersebut. Salah satu contohnya adalah dengan menjadi pemandu tur para wisata dan panitia dalam kegiatan-kegiatan sekolah lapang yang diadakan.

Pada Gambar 3, bisa dilihat bahwa pengetahuan sasaran terhadap mina eduwisata pada sebelum penyuluhan masih banyak belum mengetahui tentang pengertian, tujuan serta manfaat dari mina eduwisata. Namun, setelah penyuluhan dan diadakan post-test, sasaran sudah memahami mina eduwisata

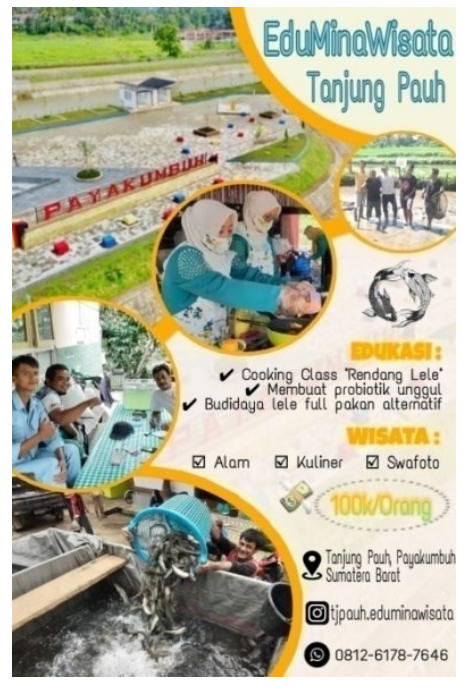

Gambar 2. Leaflet Program Mina Eduwisata

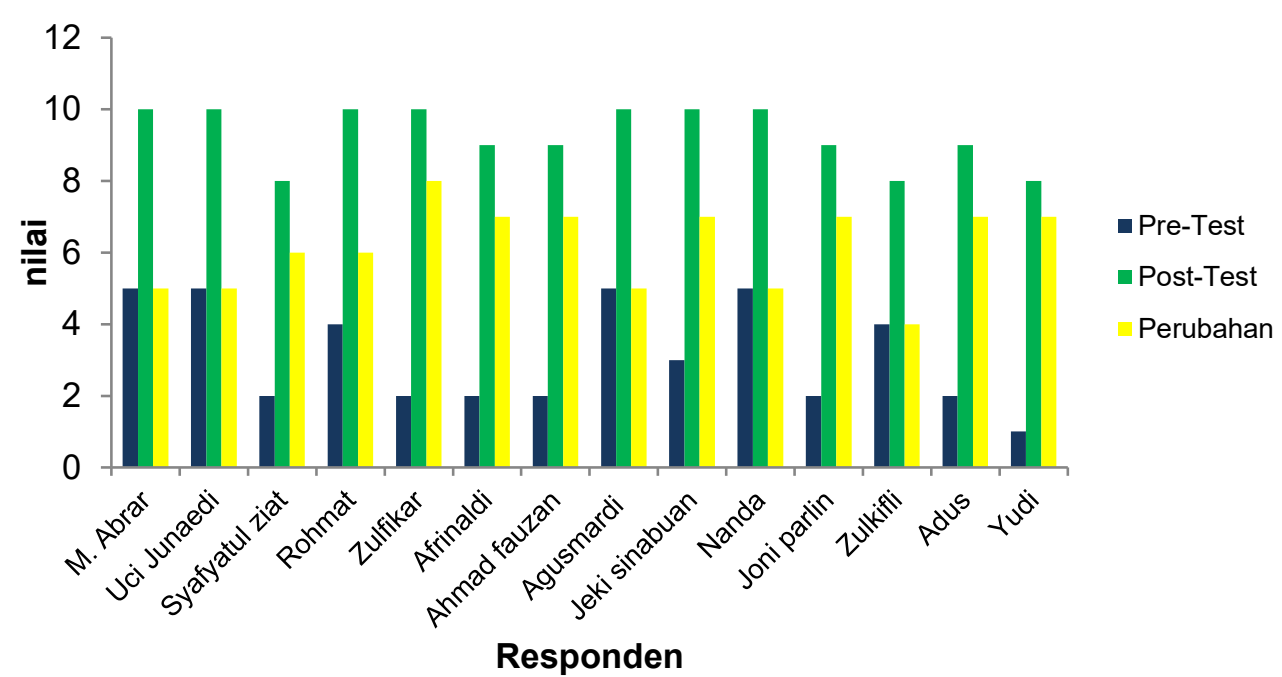

Gambar 3. Diagram Evaluasi Aspek Pengetahuan Mina Eduwisata 


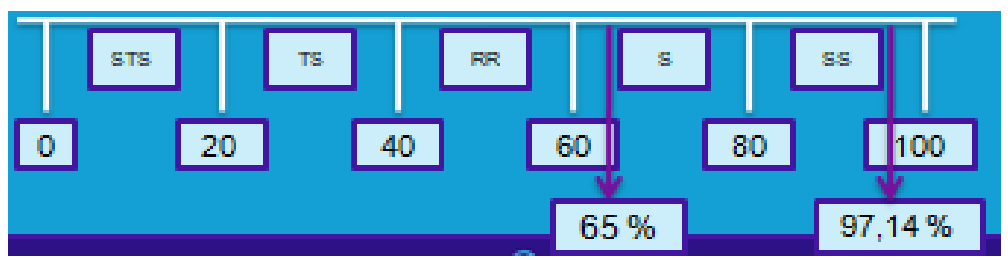

Gambar 4. Garis Kontinum Aspek Sikap Mina Eduwisata

Tabel 5.Tingkat Adopsi Mina Eduwisata

\begin{tabular}{lllllllllll}
\hline No & Kriteria & \multicolumn{7}{c}{ Pengadopsi Pada Setiap Minggu } \\
\cline { 3 - 10 } & & M1 & M2 & M3 & M4 & M5 & M6 & M7 & M8 \\
\hline 1 & Sadar & 14 & 14 & 10 & 3 & 3 & & & \\
2 & Minat & & & 4 & 4 & 4 & 3 & & \\
3 & Menilai & & & & 7 & 7 & 8 & 6 & \\
4 & Mencoba & & & & & & 3 & 8 & \\
5 & Menerapkan & & & & & & & & 14 \\
& Jumlah & 14 & 14 & 14 & 14 & 14 & 14 & 14 & 14 \\
\hline
\end{tabular}

tersebut. Keberhasilan dari penyuluhan ini, dipengaruhi oleh bagaimana pendekatan yang dilakukan kepada sasaran serta bagaimana kredibilitas dari seorang penyuluh. Adapun evaluasi aspek sikap yang dituangkan pada garis kontinum bisa dilihat pada gambar 4. Gambar 4 menunjukkan perbedaan sikap sasaran sebelum diadakannya penyuluhan. Artinya sasaran sudah menujukan sikap sangat setuju pada manfaat dari konsep mina eduwisata ini. Adapun tingkat adopsi sasaran bisa dilihat pada Tabel 5 .

Tabel 5 menunjukkan bahwa, pada minggu 8 sasaran sudah menerapkan sebanyak 14 orang. Dari konsep mina eduwisata yang memiliki 3 bagian, diantaranya mina, edukasi, dan wisata, sasaran yang berjumlah 14 orang sudah menerapkan di 3 elemen tersebut. Selain itu, masyarakat yang berada di kelurahan tanjung pauh sudah mengadopsi dari kampung mina eduwisata. Hal yang mereka terapkan adalah keterlibatan mereka pada program-program yang akan dijalankan, seperti program sekolah lapang, demcar olahan makanan dari ikan, dan lainnya.

\section{Dempond Probiotik}

Menurut Gatesoupe (2008) dalam Wardika, Suminto, dan Sudaryono (2014) probiotik merupakan sel-sel mikroba yang diberikan dengan cara tertentu agar masuk ke dalam tubuh ikan yang memiliki pengaruh menguntungkan bagi hewan inang yang mengonsum- 
Tabel 6. Kandungan Dari Bahan Pembuatan Fermentasi Probiotik

\begin{tabular}{lcc}
\hline \multicolumn{1}{c}{ Jenis Herbal } & Jenis Zat Bioaktif & Kandungan (\%) \\
\hline Temulawak & Kurkumin & 2,33 \\
& Minyak Atsiri & 6,55 \\
Kunyit & Kurkumin & 8,6 \\
& Minyak Atsiri & 6,18 \\
Jahe & Minyak Atsiri & 2,49 \\
Kencur & Kurkumin & 0,006 \\
& Minyak Atsiri & 3,35 \\
Bawang Putih & Allicin & - \\
\hline
\end{tabular}

Sumber: Laboratorium Kimia Organik FMIPA (Agustina, Mujnisa, dan Jamila 2009)

sinya dan dengan tujuan memperbaiki kesehatan. Sesuai juga dengan pendapat Ahmadi, Iskandar, dan Kurniawati (2012) menerangkan kalau prinsip dasar kerja dari probiotik ialah menggunakan kemahiran mikroorganisme dalam memecah rantai panjang protein, karbohidrat, serta lemak terhadap pakan yang dikasihkan.

Kandungan yang terdapat dari tanaman herbal yang dipakai dalam fermentasi probiotik bisa dilihat pada Tabel 6. Bawang putih mempunyai zat nutrisi khusus yaitu berupa ikatan asam amino yang disebut allicin. Allicin merupakan zat aktif yang dapat membunuh kuman-kuman penyakit bersifat anti bakteri dan kurkumin juga mempunyai sifat yang dapat menghambat perkembangan bakteri karena bersifat antiseptik (Sahara 2020). Minyak atsiri dalam bawang putih berperan selaku antibiotik, serta bisa menetralkan toksin, tingkatkan sekresi empedu, sehingga bisa tingkatkan nafsu makan pada ikan, perihal ini karna kurkumin serta minyak atsiri bisa memperbaiki kerja sistem pencernaan serta digunakan sebagai bahan pemacu perkembangan serta menambah energi cerna (Setianingrum 1999 dalam Rahmi, Darmawan, dan Abil 2014)

Kandungan yang terdapat di air cucian beras adalah sebagai sumber karbon alternatif karena mengandung karbon dan memiliki gugus monosakarida dan disakarida terutama glukosa, fruktosa, sukrosa dan pati. Di mana lebih mudah dimanfaatkan oleh bakteri secara langsung dan asupan energi untuk bakteri selalu tersedia (Sitohang, Fitrani, dan Jubaedah 2018). Kandungan gula yang cukup tinggi pada gula aren digunakan oleh mikroba untuk bermetabolisme. Mikroba akan menghidrolisis kandungan sukrosa pada nira aren yang kemudian diubah menjadi karbohidrat 
Tabel 7. Perbedaan Kualitas Air Kolam Dempond Probiotik

\begin{tabular}{llcccl}
\hline No & Parameter & Kolam 1 & Kolam 2 & Kolam 3 & Kelayakan Menurut Pustaka \\
\hline 1 & $\mathrm{PH}$ & 7,7 & 7,7 & 7,5 & $6,5-8,5(\mathrm{SNI} 01-6483.4-2000)$ \\
2 & Amoniak & 0,2 & 0,2 & 0,2 & $<0,2 \mathrm{ppm}($ Boyd, 1990) \\
3 & suhu & 28 & 28 & 28 & $27-30^{\circ} \mathrm{C}(\mathrm{SNI}$ 01-6483.4-2000) \\
\hline
\end{tabular}

yang lebih sederhana sehingga dapat digunakan dalam proses metabolisme (Astuti, Rochmayani, dan Aulia 2018)

Kolam percontohan pada penelitian ini di kelola sesuai CBIB. Dan pada tahap sebelum penebaran benih, probiotik sudah di terapkan untuk kolam 2 dan 3. Pemberian probiotik sebelum ditebar ikan bertujuan untuk menumbuhkan pakan alami atau plankton. Sedangkan pada kolam 1 yaitu kolam yang tidak menggunakan Probiotik.

Pada kegiatan Dempond pembesaran ikan lele, pengontrolan kualitas air dilakukan pada kolam pemeliharaan lele mulai dari awal penebaran sampai panen. Hasil yang diperoleh dari pengelolaan kualitas air pada kolam dempond bisa dilihat pada Tabel 7 .

Hasil pengecekan kualitas air pada Tabel 7, untuk pH air tiap-tiap kolam dempond cukup stabil dan untuk suhu pun juga relatif stabil. $\mathrm{pH}$ merupakan derajat keasaman yang digunakan untuk mengukur nilai keasaman atau kebasaan dari suatu cairan sehingga kita mampu mengetahui kelayakan dari cairan tersebut (Adrianto 2018). Kendala di kolam dempond adalah tingkat amoniak di kolam-kolam dempond yang tinggi. Kandungan amoniak yang tinggi ini diakibatkan oleh pakan yang digunakan dalam proses budidaya, yaitu pakan kulit dan usus ayam. Menurut Craigh dan Helfrich (2002) dalam Rachmawati, Samidjan, dan Setyono (2015) meskipun melalui manajemen yang baik, pakan yang diberikan pada ikan pasti akan menghasilkan limbah. Dari 100\% pakan, lazimnya $10 \%$ tidak termakan, $10 \%$ ialah limbah padatan, serta 30\% ialah limbah cair yang dihasilkan oleh ikan. Dari sisanya, $25 \%$ digunakan buat berkembang serta $25 \%$ yang lain buat metabolisme. Limbah yang sangat berisiko serta bertabiat toksik untuk ikan, khususnya merupakan amoniak. Selain bersifat toksik bagi kolam budidaya, ternyata limbah dari kolam budidaya ini juga bermanfaat bagi sawah di sekitarnya, karena bisa menjadi pupuk untuk tanaman padi. Laju perbedaan pertumbuhan ikan lele dari kolam dempond bisa dilihat pada Tabel 8.

Berdasarkan data di Tabel 8, laju pertumbuhan panjang dan berat ikan lele meningkat setiap sampling. Dapat dibandingkan hasil berat dan panjang tercepat 
Tabel 8. Perbedaan Laju Pertumbuhan Dari Kolam Percontohan

\begin{tabular}{|c|c|c|c|c|c|c|c|}
\hline \multirow{3}{*}{ No } & \multirow{3}{*}{ Hari Ke- } & \multicolumn{6}{|c|}{ Kolam Perlakuan } \\
\hline & & \multicolumn{2}{|r|}{1} & \multicolumn{2}{|c|}{2} & \multicolumn{2}{|r|}{3} \\
\hline & & $\begin{array}{l}\text { Berat } \\
\text { gr }\end{array}$ & $\begin{array}{l}\text { Panjang } \\
\mathrm{cm}\end{array}$ & $\begin{array}{l}\text { Berat } \\
\text { gr }\end{array}$ & $\begin{array}{l}\text { Panjang } \\
\mathrm{cm}\end{array}$ & $\begin{array}{l}\text { Berat } \\
\text { gr }\end{array}$ & $\begin{array}{l}\text { Panjang } \\
\mathrm{cm}\end{array}$ \\
\hline 1 & M2 & 50 & 17 & 50 & 17 & 50 & 17 \\
\hline 2 & M4 & 88 & 22 & 80 & 20,5 & 102 & 23 \\
\hline 3 & M6 & 133 & 26,5 & 121,6 & 25 & 161 & 27 \\
\hline 4 & M8 & 202 & 29 & 183 & 28,8 & 211 & 30,5 \\
\hline
\end{tabular}

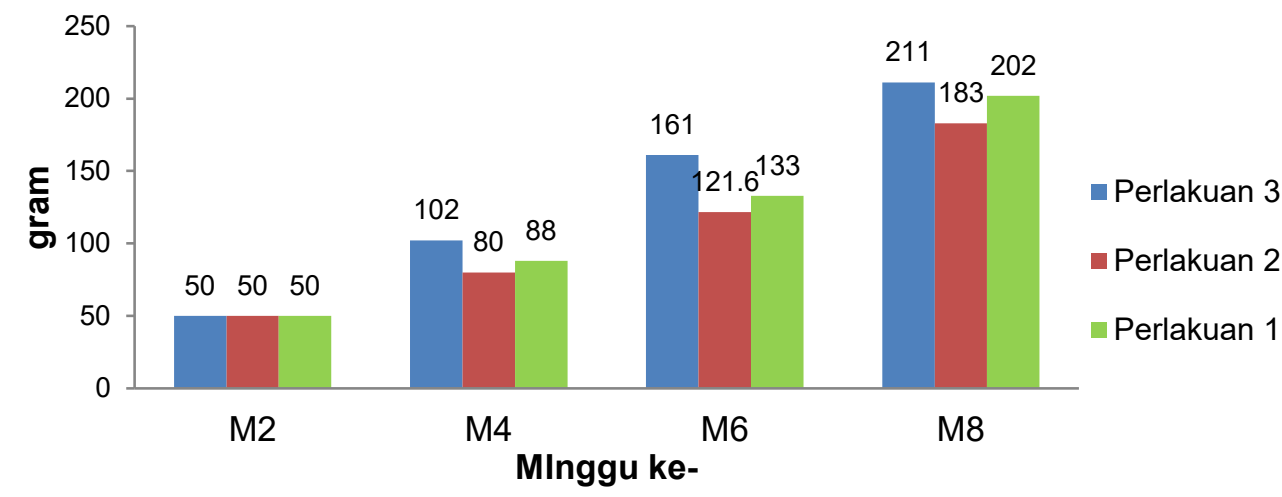

Gambar 5. Grafik Perbedaan Laju Pertumbuhan Ikan Lele Dempond

dari ketiga perlakuan tersebut adalah perlakuan 3 memiliki pertumbuhan berat rata-rata $211 \mathrm{gr}$ dengan panjang rata-rata $30,5 \mathrm{~cm}$ pada minggu ke 8 . Kemudian pertumbuhan tercepat selanjutnya adalah perlakuan 1 yang memiliki pertumbuhan berat rata-rata $202 \mathrm{~g}$ dengan panjang $29 \mathrm{~cm}$ pada minggu ke 8 . Selanjutnya adalah perlakuan 2 yang memiliki pertumbuhan berat rata-rata $183 \mathrm{~g}$ dengan panjang $28,8 \mathrm{~cm}$ pada minggu ke 8. Meretsky et al. (2000) dalam Kusmini et al. (2018) menuturkan kalau transformasi bobot ikan bisa dihasilkan dari perubahan pakan serta bagian tenaga untuk berkembang serta reproduksi, yang menyebabkan berat ikan berbeda meski panjangnya sama.

Dosis yang digunakan dalam penelitian ini melalui Pemberian probiotik pada pakan yaitu dengan cara mencampurkan $10 \mathrm{ml}$ fermentasi probiotik untuk $1 / 2 \mathrm{~kg}$ pakan, kemudian pakan ditambah air bersih sebanyak $200 \mathrm{ml}$. Sedangkan untuk pemberian probiotik pada media air yaitu sebanyak $10 \mathrm{ml}$ fermentasi probiotik diencerkan dengan air secukupnya, kemudian ditebar secara merata di permukaan kolam. Grafik laju per- 
tumbuhan berat ikan lele bisa dilihat pada Gambar 5.

Pengendalian hama dan penyakit pada kolam dempond ialah dengan memperhatikan bulu ayam sisa dari pemberian pakan. Bulu ayam yang mengapung pada permukaan kolam kalau tidak cepat dibersihkan maka akan tenggelam dan menjadi sumber penyakit dan amoniak serta jadi pemicu tumbuhnya parasit dan bakteri. Penyakit akibat infeksi bakteri pada ikan ternyata bisa mengakibatkan kematian ikan dari 50\%-100\% (Rahmaningsih 2018). Selain itu juga, penulis juga memberikan multivitamin untuk pencegahan hama dan penyakit.

Hasil panen kolam dempond dari perbedaan perlakuan penerapan probiotik bisa dilihat pada tabel 9 .
Berdasarkan Tabel 9, dapat dilihat perbandingan antara perlakuan probiotik pada tiap kolam. Dari hasil perbandingan tersebut dapat dilihat bahwa hasil dari kolam 3 dengan perlakuan probiotik melalui media pakan dan air lebih baik dibandingkan dengan kolam 1 dengan perlakuan probiotik media pakan dan kolam 2 dengan perlakuan probiotik media air. Dari nilai FCR, Mortalitas, SR, Produktivitas, berat panen lebih baik kolam 3 yang menerapkan probiotik pada media pemberian pakan dan air. Menurut Aquarista dan Subhan (2012) survival rate atau Kelangsungan hidup merupakan perbandingan antara jumlah organisme yang hidup pada akhir periode dengan organisme yang hidup di awal periode. Perhitungan rasio konversi pakan adalah dengan menghitung jum-

Tabel 9. Data Perbedaan Data Hasil Panen Kolam Dempond

\begin{tabular}{llccc}
\hline \multirow{2}{*}{ No } & \multicolumn{1}{c}{ Kategori } & \multicolumn{3}{c}{ Kolam Percontohan } \\
\cline { 3 - 5 } & & $\mathbf{1}$ & $\mathbf{2}$ & $\mathbf{3}$ \\
\hline 1 & Padat Tebar (ekor/m $\left.{ }^{2}\right)$ & 51 & 51 & 51 \\
2 & Luas Kolam $\left(\mathrm{m}^{2}\right)$ & 117 & 117 & 117 \\
3 & Jumlah Tebar (ekor) & 6000 & 6000 & 6000 \\
4 & Ukuran Tebar (gram) & 50 & 50 & 50 \\
5 & Panen (kg) & 982 & 970 & 1024 \\
6 & Ukuran Panen (gram) & 202 & 183 & 211 \\
7 & Pakan Kumulatif (kg) & 600 & 600 & 600 \\
8 & FCR & 0,6 & 0,6 & 0,5 \\
9 & SR (\%) & 81 & 80 & 85 \\
10 & Mortalitas (\%) & 19 & 20 & 15 \\
11 & Produktivitas (ekor $\left./ \mathrm{m}^{2}\right)$ & 42 & 41,5 & 44 \\
\hline
\end{tabular}


Tabel 10. Perbandingan Analisis Usaha Kolam Dempond

\begin{tabular}{llrrr}
\hline \multirow{2}{*}{ No } & \multicolumn{1}{c}{ Parameter } & \multicolumn{3}{c}{ Kolam perlakuan } \\
\cline { 3 - 5 } & & Rp. 460.000 & Rp. 460.000 & Rp. 460.000 \\
\hline 1 & Investasi & Rp. 7.148 & Rp. 7.148 & Rp. 7.148 \\
2 & Penyusutan (bulan) & Rp. 257.148 & Rp. 57.148 & Rp. 257.148 \\
3 & Biaya tetap (bulan) & Rp. 6.150.000,- & Rp. 6.150.000,- & Rp. 6.150.000,- \\
4 & Biaya variabel & Rp. 6.664.296,- & Rp. 6.264.296,- & Rp. 6.664.296,- \\
5 & Total biaya produksi/siklus & Rp 13.748.000 & Rp 13.580.000 & Rp. 14.336.000 \\
6 & Total Pendapatan & Rp. 7.115.704,-- & Rp. 7.315.704,- & Rp. 7.671.704,- \\
7 & Keuntungan/siklus & Rp. 28.462.816 & Rp. 29.262.816 & Rp. 30.686.816 \\
8 & Keuntungan/tahun & 2,06 & 2,16 & 2,15 \\
9 & R/C Ratio & 476 & 447 & 476 \\
10 & BEP Unit (kg) & $6.786,-$ & $6.450,-$ & $6.508,-$ \\
11 & BEP Rupiah & 0,06 & 0,06 & 0,05 \\
12 & Payback Period & & & \\
\hline
\end{tabular}

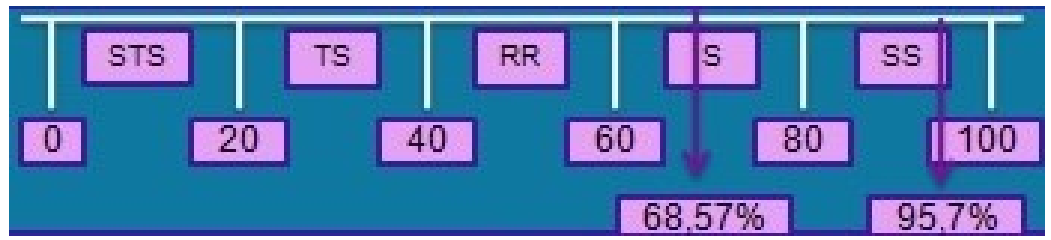

Gambar 6. Garis Kontinum Aspek Sikap Dempond

lah pakan yang digunakan sepanjang produksi dibagi peningkatan berat badan ikan yang dihasilkan sepanjang pemeliharaan (Santoso 2014). Menurut USAID (2011) dalam Salsabila dan Suprapto (2019) semakin kecil nilai FCR, maka menunjukkan indikasi baik dari pakan berkualitas tinggi.

Penghitungan analisis usaha dilakukan setelah pemeliharaan ikan selama \pm 60 hari kolam dempond, bisa dilihat pada tabel 10. Alur pemasaran dari hasil panen kolam dempond ikan lele dengan penerapan probiotik ini adalah pembudidaya ke pengepul ke distributor dan terakhir ke konsumen. Adapun evaluasi aspek sikap pada kegiatan kolam dempond bisa dilihat pada gambar 6 .

Dari garis kontinum di Gambar 6 bisa dilihat bahwa sikap sasaran sudah meningkat setelah diadakannya penyuluhan. Jika nilai post-test garis kontinum meningkat dari sebelum pre-test artinya sasaran sudah pada tahap sangat setuju dengan inovasi yang diberikan. Perubah- 


\begin{tabular}{|llccccccccc|}
\hline \multicolumn{8}{c|}{ Tabel 11. Tingkat Adopsi Dempond Probiotik } \\
\hline \multirow{2}{*}{ No } & \multirow{8}{*}{ Kriteria } & \multicolumn{7}{c|}{ Pengadopsi Pada Setiap Minggu } \\
\cline { 2 - 10 } & & M1 & M2 & M3 & M4 & M5 & M6 & M7 & M8 \\
\hline 1 & Sadar & 10 & 7 & & & & & & \\
2 & Minat & 4 & 7 & 4 & 3 & 3 & 3 & 3 & 3 \\
3 & Menilai & & & 7 & 3 & 3 & 3 & 1 & 1 \\
4 & Mencoba & & & & 5 & 2 & 2 & 2 & 2 \\
5 & Menerapkan & & & 3 & 3 & 6 & 6 & 8 & 8 \\
& Jumlah & 14 & 14 & 14 & 14 & 14 & 14 & 14 & 14 \\
\hline
\end{tabular}

an aspek sikap dari sasaran itu disebabkan oleh inovasi yang telah diperoleh. Setiap orang akan tertarik terhadap sesuatu yang baru apabila hal tersebut bermanfaat baginya.

Sasaran yang mengadopsi probiotik pada minggu ke 8 sudah sebanyak 8 orang, artinya pada kelompok Kincia Solok Mato Aia sudah mengadopsi $60 \%$ dari total jumlah anggota Pokdakan. Pada tahap mencoba sudah ada 2 orang, sasaran ini sudah melihat langsung hasil dari dempond probiotik tersebut, hanya saja mereka masih mencoba menggunakan probiotik yang dibuat oleh anggota lain. Inovasi yang diberikan kepada sasaran akan dipengaruhi oleh beberapa hal baik berupa sifat inovasi, sifat pengadopsi dan sifat pengantar perilaku perubahan. Adopsi dalam penyuluhan adalah proses penerimaan inovasi serta ataupun pergantian perilaku baik yang berbentuk: pengetahuan, sikap, ataupun keterampilan pada diri seorang sesudah menerima inovasi yang di informasikan penyuluh terhadap target (Mardikanto 2009).

\section{Azolla microphylla}

Sosialisasi pemanfaatan pakan alami Azolla microphylla yang ditujukan untuk pembudidaya ikan nila yang berada di Pokdakan Tobek Ngoji Jaya adalah bentuk dari penambahan program kegiatan dalam menumbuhkan kampung mina eduwisata. Azolla microphylla dipilih karna merupakan jenis tanaman paku yang tinggi akan protein dibandingkan tanaman-tanaman yang biasa digunakan oleh pembudidaya biasanya seperti daun talas dan sebagainya. Sesuai dengan penelitian Prawitasari, Ismadi, dan Estiningdriati (2012), Azolla mengandung protein $31,25 \%$,lemak $7,5 \%$, karbohidrat $6,5 \%$, dan serat kasar $13 \%$,. Tumbuhan paku Azolla microphylla mempunyai keunggulan dari segi perkembangan yang kilat serta gampang untuk dikembangkan 


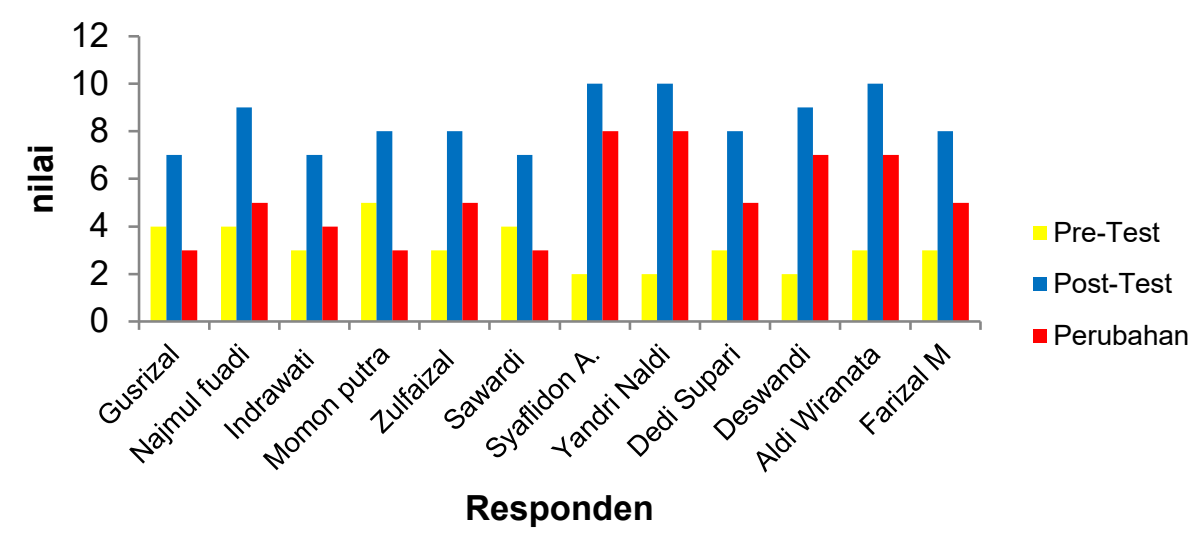

Gambar 7. Grafik Evaluasi Aspek Pengetahuan Sosialisasi Azolla microphylla

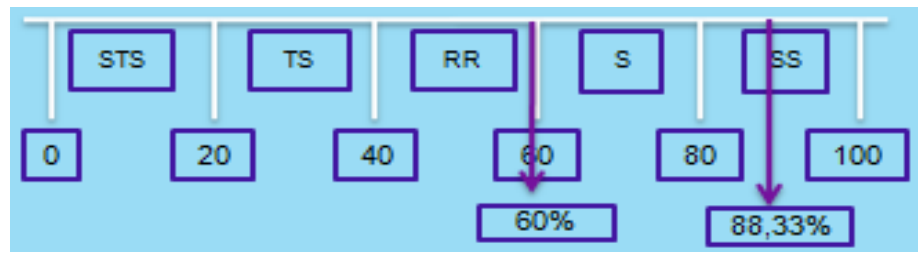

Gambar 8. Garis Kontinum Evaluasi Aspek Sikap Sosialisasi Azolla microphylla

sendiri, apalagi dalam proses budidayanya lumayan gampang. Laju pertumbuhan azolla adalah 0,355-0,390 gram per hari (di laboratorium) dan 0,144-0,860 g per hari(di lapangan) (Leanne M 2010). Adapun evaluasi aspek pengetahuan responden terhadap sosialisasi pemanfaatan pakan alami Azolla microphylla pada Gambar 7.

Sasaran pada kegiatan sosialisasi Azolla microphylla menunjukkan progresif yang baik dari segi pengetahuannya setelah diadakannya penyuluhan. Hal ini tentu membawa dampak baik bagi keberlanjutan dari penumbuhan mina eduwisata maupun manfaat bagi sasaran yang mengadopsi inovasi tersebut. Adapun evaluasi aspek sikap sasaran yang dituangkan dalam garis kontinum bisa dilihat pada Gambar 8.

Aspek sikap dari sasaran sosialisasi Azolla microphylla menunjukkan perubahan yang baik, yaitu peningkatan sebanyak $28,33 \%$ di mana sikap sasaran yang masih di antara ragu-ragu dan setuju sudah meningkat dan berubah menjadi sangat setuju dengan inovasi pakan alami Azolla microphylla. Perubahan ini dilandasi oleh keinginan sasaran yang tertarik jika memperlihatkan keuntungan akan meningkat dari hasil budidaya jika menerapkan pakan alami Azolla microphylla. 


\section{SIMPULAN DAN SARAN}

\section{Simpulan}

Mina eduwisata yang dikembangkan di Kelurahan tanjung Pauh dengan melibatkan semua elemen-elemen terkait di dalamnya pada tanggal 14 Juni 2021 resmi dikukuhkan oleh Camat Payakumbuh Barat, Kota Payakumbuh. Hal ini tercantum dalam Berita Acara pengukuhannya dan juga di promosikan lewat media Stasiun Padang TV. Mina Eduwisata ini akan memberi manfaat yang banyak bagi kelurahan Tanjung Pauh seperti menaikkan ekonomi masyarakat perikanan dan non perikanan, memperkenalkan UMKM di bidang lain, dan memberdayakan karang taruna, serta progresif untuk Tanjung Pauh tentunya.

Inovasi penerapan penggunaan probiotik pada usaha budidaya ikan lele dengan penelitian melalui metode demonstrasi percontohan yang memiliki pertumbuhan yang paling cepat adalah kolam perlakuan 3 (pakan dan air) memiliki berat akhir $211 \mathrm{gr}$ panjang $30,5 \mathrm{~cm}$. Kemudian perlakuan 1 (pakan) memiliki berat $202 \mathrm{gr}$ panjang $29 \mathrm{~cm}$, dan terakhir perlakuan 2 dengan berat akhir $183 \mathrm{gr}$ panjang 28,8 cm. Dari hasil data Dempond bisa dinilai bahwa penerapan probiotik pada media pakan dan air hasilnya adalah definitif untuk meningkatkan produksi dari usaha budidaya ikan lele. Melihat dari kandungan dari bahan-bahan Probiotik bisa disimpulkan bahwa proses budidaya lebih Korektif dan Kuratif dalam menjaga kesehatan ikan.

Sosialisasi Azolla microphylla telah membawa dampak baik bagi pembudidaya ikan nila. Selama ini mereka belum mengetahui azolla microphylla, dan manfaat dari Azolla microphylla sendiri. Setelah dilakukan penyuluhan, dan memperkenal Azolla microphyla secara langsung, pembudidaya bisa langsung menebarnya di kolam. Artinya, telah ada perubahan sikap dan pengetahuan dari sasaran dalam program penyuluhan yang dilakukan.

\section{Saran}

Dikukuhkannya Kelurahan Tanjung Pauh menjadi Kampung Mina Eduwisata semoga menjadi titik terang dari keberlanjutan perikanan yang ada di kelurahan tersebut. Dan juga pembudidaya bisa memanfaatkan keunggulan ini untuk mengembangkan dan menguatkan sektor perikanan dan ekonomi masyarakat pastinya.

Saat pelaksanaan Demonstrasi Percontohan, penulis merasa padat tebar masih rendah dan masih dapat ditingkatkan, asal sesuai dengan ukuran kolam dan juga didukung oleh penerapan CBIB yang sesuai.

Pengelolaan kolam sebelum produksi masih jarang dilakukan, kebanyakan dari pembudidaya sudah mulai 
sadar akan hal ini, tetapi rasa malas masih saja dijadikan alasan. Semoga dengan melihat perbandingan dari hasil Dempond yang sudah menerapkan CBIB menjadikan alasan pembudidaya untuk lebih memperhatikan hal yang penting ini.

Administrasi kelompok sudah baik hanya ada beberapa yang hilang, dan kekompakan kelompok juga sudah baik. Semoga lebih menjaga lagi solidaritas antar anggota supaya lebih baik lagi ke depannya. Kemudian menyimpan datadata administrasi kelompok di tempat yang aman.

Saat ini induk ikan lele yang digunakan anggota kelompok dalam usaha pembenihan, sudah bukan induk yang standar dari balai perikanan lagi. Semoga ke depannya, anggota kelompok tersebut akan menggunakan induk lele yang bersertifikat demi benih ikan lele yang unggul tentunya.

\section{DAFTAR PUSTAKA}

Adrianto, Rizki. 2018. "Pemantauan Jumlah Bakteri Coliform di Perairan Sungai Provinsi Lampung." Majalah TEGI 10(1):1-6. doi: 10.46559/tegi.v10i1.3920.

Agustina, Laily, A. Mujnisa, dan Jamila. 2009. "Peran Ramuan Herbal Dalam Jumlah Dan Bentuk Sediaan Berbeda Terhadap Performa Ayam Buras."
Ahmadi, Hendri, Iskandar, dan Nia Kurniawati. 2012. "Pemberian Probiotik dalam Pakan Terhadap Pertumbuhan Lele Sangkuriang (Clarias Gariepinus) pada Pendederan II." Jurnal Perikanan dan Kelautan Unpad 3(4):99-107. Aquarista, Fenta, dan Ujang Subhan. 2012. "Pemberian probiotik dengan carrier zeolit pada pembesaran ikan lele dumbo (Clarias gariepinus)." Jurnal Perikanan dan Kelautan 3(4):133-40.

Astuti, Asri, Maulida Rochmayani, dan Ranti Aulia. 2018. "Nawake (Nira Water Kefir): Pemanfaatan Nira Aren Sebagai Minuman Fungsional Kaya Probiotik." Agritech 20(1):712.

BPS. 2020. Payakumbuh Barat dalam Angka 2020. Payakumbuh (ID): Badan Pusat Statistik Kota Payakumbuh.

Diniyah, Fitrotud. 2018. "Pengaruh Daya Tarik Wisata Terhadap Minat Kunjungan Ulang Wisatawan di Museum Benteng Vredeburg Yogyakarta." (0274):1-5. doi: 10.31219/osf.io/vjf78.

Hanan, Abdul, Walson H. Sinaga, dan Nayu Nurmalia. 2012. "Hubungan Karakteristik Pelaku Utama Perikanan dengan Kebutuhan Materi Penyuluhan Perikanan (Studi 
Kasus di Kabupaten Purbalingga

Provinsi Jawa Tengah." Jurnal

Penyuluhan Perikanan dan

Kelautan 6(1):1-11. doi:

10.33378/jppik.v6i1.29.

Kusmini, Irin Iriana, Deni Radona, dan

Fera Permata Putri. 2018. "Pola

Pertumbuhan dan Faktor Kondisi

Benih Ikan Tengadak ( Barbonymus

Schwanenfeldii ) pada Wadah

Pemeliharaan yang Berbeda."

LIMNOTEK Perairan Darat Tropis di Indonesia 25(1):1-9. doi:

10.14203/limnotek.v25i1.186.

Leanne M, Paulus. 2010. "Pemanfaatan

Azolla Sebagai Pupuk Organik pada

Budidaya Padi Sawah." Warta WIPTEK 36:68-72.

Lestari, Susi. 2010. "Pengembangan

Desa Wisata Dalam Upaya

Pemberdayaan Masyarakat Studi Di

Desa Wisata Kembang Arum,

Sleman [Skripsi]." Universitas Islam

Negeri Kalijaga.

Mardikanto, Totok. 2009. Sistem

Penyuluhan Pertanian. Surakarta

(ID): UNS Press.

Prawitasari, Rahayuningtyas Harum,

Vitus Dwi Yunianto Budi Ismadi, dan

Ismari Estiningdriati. 2012.

“Kecernaan Protein Kasar dan Serat

Kasar Serta Laju Digesta pada

Ayam Arab yang Diberi Ransum

dengan Berbagai Level Azolla microphylla." Animal Agriculture Journal 1(1):471-83.

Rachmawati, Diana, Istiyanto Samidjan, dan Heryoso Setyono. 2015. "Manajemen Kualitas Air Media Budidaya Ikan Lele Sangkuriang (Clarias Gariepinus) dengan Teknik Probiotik pada Kolam Terpal di Desa Vokasi Reksosari, Kecamatan Suruh, Kabupaten Semarang." PENA Akuatika 12(1):24-32.

Rahmaningsih, Sri. 2018. Hama dan Penyakit Ikan. Yogyakarta: Deepublish.

Rahmi, Darmawan, dan Muh. Abil. 2014. "Pemanfaatan Minyak Atsiri dari Bawang Putih (Allium Sativum) sebagai Antibiotik Ikan Mas (Cyprinus Carpio Linn)." Octopus Jurnal IImu Perikanan 3(1):204-10. doi: 10.26618/octopus.v3i1.537.

Sahara, Eli. 2020. "Peran Jamu Hewan Untuk Antisipasi Penyakit ND (Newcastel Desease) pada Ternak Unggas." Jurnal Pengabdian Sriwijaya 8(2):1028-33. doi: 10.37061/jps.v8i2.12434.

Salsabila, Meidiana, dan Hari Suprapto. 2019. "Teknik Pembesaran Ikan Nila (Oreochromis Niloticus) di Instalasi Budidaya Air Tawar Pandaan, Jawa Timur." Journal of Aquaculture and Fish Health 7(3):118. doi: 
10.20473/jafh.v7i3.11260.

Santoso, Rachmat. 2014. "Penambahan

Atraktan yang Berbeda dalam

Pakan Buatan Pasta terhadap

Pertumbuhan dan Feed Convertion

Ratiobelut (Monopterus Albus) dengan Sistem Resirkulasi

[Skripsi]." Universitas Airlangga.

Sitohang, Martogi Leo, Mirna Fitrani, dan

Dade Jubaedah. 2018.

"Pemanfaatan Campuran Buah

Nanas, Air Cucian Beras, dan Gula

Sebagai Sumber Karbon pada

Media Pemeliharaan Ikan Lele

(Clarias sp) dengan Sistem Bioflok."

Jurnal Akuakultur Rawa Indonesia 6(1):51-64.

doi:

10.36706/jari.v6i1.7149.

Sudarmadji, Pramono Hadi, dan M.

Widyastuti. 2014. Pengelolaan
Sumber Daya Air Terpadu.

Yogyakarta (ID): Gadjah Mada

University Press.

Tanto, Dwi, Sri Murni Dewi, dan Sugeng P. Budio. 2012. "Faktor-Faktor yang Mempengaruhi Produktivitas Pekerja pada Pengerjaan Atap Baja Ringan di Perumahan Green Hills Malang." Rekayasa Sipil 6(1):6982.

Wardika, Aziz Sinung, Suminto, dan Agung Sudaryono. 2014. "Pengaruh Bakteri Probiotik pada Pakan dengan Dosis Berbeda Terhadap Efisiensi Pemanfaatan Pakan, Pertumbuhan dan Kelulushidupan Lele Dumbo (Clarias gariepinus)." Journal of Aquaculture Management and Technology 3(4):9-17. 